Abstract

\title{
Fruit-Associated Endophytes from Olive Cultivars with Different Levels of Resistance to Fruit Fly and Their Relationship with Pest Infestation ${ }^{\dagger}$
}

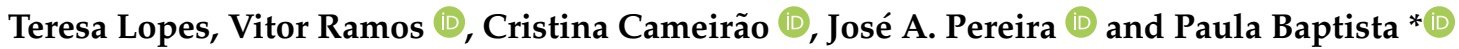

Citation: Lopes, T.; Ramos, V.; Cameirão, C.; Pereira, J.A.; Baptista, P. Fruit-Associated Endophytes from Olive Cultivars with Different Levels of Resistance to Fruit Fly and Their Relationship with Pest Infestation. Biol. Life Sci. Forum 2021, 4, 9. https://doi.org/10.3390/IECPS 2020-08880

Academic Editor: Yoselin

Benitez-Alfonso

Published: 3 December 2020

Publisher's Note: MDPI stays neutral with regard to jurisdictional claims in published maps and institutional affiliations.

Copyright: (c) 2020 by the authors. Licensee MDPI, Basel, Switzerland. This article is an open access article distributed under the terms and conditions of the Creative Commons Attribution (CC BY) license (https:// creativecommons.org/licenses/by/ $4.0 /)$.
Centro de Investigação de Montanha (CIMO), Instituto Politécnico de Bragança, Campus de Santa Apolónia, 5300-253 Bragança, Portugal; d.teresalopes@gmail.com (T.L.); vramos@ipb.pt (V.R.); ccameirao@ipb.pt (C.C.); jpereira@ipb.pt (J.A.P.)

* Correspondence: pbaptista@ipb.pt

+ Presented at the 1st International Electronic Conference on Plant Science, 1-15 December 2020; Available online: https://iecps2020.sciforum.net/.

\begin{abstract}
Olive fruit fly, Bactrocera oleae (Rossi) (Diptera: Tephritidae), is the most important olive pest, with major economic importance in olive production worldwide. Different olive cultivars exhibit different propensities to fruit fly infestation and the causes are still unclear. Here, we want to disclose the potential role of olive-associated endophytes in conferring such susceptibility differences. Accordingly, the endophytic microbial composition of infested and non-infested fruits from cultivars Madural (susceptible to olive fly) and Cobrançosa (less susceptible) were studied. A culture-dependent approach was used, the isolates being identified by sequencing of their internal transcribed spacer (for fungi) and 16S rRNA gene regions (for bacteria). Overall, there was a larger consortium of bacteria associated with olives than fungi. The bacterial communities were predominantly composed of Proteobacteria and Actinobacteria phyla, while the fungal isolates belonged to the Ascomycota and Basidiomycota. Both host cultivar and level of fly infestation had a negligible effect on fungal and bacterial community composition. Despite this, a clear positive association of microbial consortia with the resistant cultivar (Kocuria sp., Actinobacterium sp., Rhodococcus sp., Pseudomonas citronellolis, Aspergillus flavus, Cladosporium sp., and Meristemomycetes arctostaphylos) and non-infested fruits (Kocuria sp., Stereum sp., and Vishniacozyma victoria) was found. Their functional roles in host cultivar susceptibility/resistance to the fruit fly is a topic that requires further studies.
\end{abstract}

Keywords: Bactrocera oleae rossi; susceptibility of olive cultivars; bacteria; fungi; biocontrol

Supplementary Materials: The poster presentation is available online at https: / www.mdpi.com/ article/10.3390/IECPS2020-08880/s1.

Institutional Review Board Statement: Not applicable.

Informed Consent Statement: Not applicable.

Acknowledgments: This work was supported by FEDER funds through the COMPETE (Operational Programme for Competitiveness Factors) and by national funds through the FCT (Foundation for Science and Technology) within the POCI-01-0145-FEDER-031133 (MicOlives) project. 